\title{
Az elkövető személyiségének jelentősége a büntetéskiszabásban, különös tekintettel az előéletre
}

\author{
The Importance of the Offender's Personality in the Infliction Process, \\ Particularly as Regards the Criminal Records
}

\begin{abstract}
ABSZTRAKT
A büntetéskiszabás folyamatában a terhelt személyi körülményeinek vizsgálatához hozzátartozik elöéletének alapos feltárása is, vagyis annak kiderítése, hogy követett-e el korábban büncselekményt, volt-e büntetve, s amennyiben igen, akkor hányszor, mikor, milyen büncselekmény miatt, és végül, de nem utolsósorban, hogy milyen büntetési nemre itélték. Ezek a tényezők ugyanis nagymértékben befolyásolhatják a kiszabott büntetést, hiszen a büntetlen elöéletet többnyire enyhítő körülményként veszi figyelembe a bíróság, míg a bünismétlökre, visszaesőkre, mint a társadalomra fokozott veszélyt jelentő elkövetőkre, szigorúbb büntetőjogi szabályok vonatkoznak. Az elmúlt néhány évtized hazai büntetőjogi szakirodalma meglehetösen szükölködik az elkövetö előéletének alaposabb vizsgálatát végző tanulmányokban. Ezért írásommal és kutatásommal a szakirodalom ebbéli adósságait is szeretném törleszteni, azzal, hogy ezúttal az elkövető elöéletét mint büntetéskiszabási szempontot vizsgálom. Célom, hogy bemutassam a hatályos jogszabályi környezeten túl az elkövető elóélete kapcsán kialakult és követett birói gyakorlatot, és annak esetleges anomáliáira is felhívjam a figyelmet.
\end{abstract}

Kulcsszavak: büntetéskiszabás, személyi körülmények, az elkövető előélete, bírói gyakorlat, visszaeső

\begin{abstract}
During the infliction process, the judiciary needs to take into account the accused person's personal circumstances, a process which also consists of the thorough exploration of the criminal records of the accused. It has to be considered whether the accused has committed any crime, and has been sentenced before, and if they have been, how many times, when, for what crime, and, last but not least, what the sentence was. These factors may greatly influence the inflicted punishment as a clean record is usually considered by the judiciary as a mitigating circumstance, while recidivists, offenders who pose an increased risk to society, are more seriously penalised. The penal literature of the last few decades lacks thorough studies on the previous criminal records of offenders. In my study paper and research, I attempt to make up for this shortage by examining the criminal records of the offender as a criterion of the infliction process. My aim is to present the actual judicial practise beyond the effective legislative environment and call attention to certain anomalies.
\end{abstract}

Keywords: infliction process, personal circumstances, criminal records, judicial practise, recidivist

* Dr. Pápai-Tarr Ágnes, egyetemi adjunktus, Debreceni Egyetem Állam- és Jogtudományi Kar, Büntetőjogi és Kriminológiai Tanszék; e-mail: papai-tarr.agnes@law.unideb.hu. A tanulmány a Bolyai János Kutatási Ösztöndíj támogatásával készült. 
Büntetőjogunk egyik klasszikus alapelve a tett-büntetőjogi szemlélet, mely szerint a büntetőjogi felelősségre vonás alapja az elkövetett büncselekmény. ${ }^{1}$ Régi elv ez, mely a felvilágosodás haladó gondolataként jelent meg először, elsősorban a rendi kiváltságok büntetőjogban történő felszámolása és a törvény előtti egyenlőség megteremtésének jegyében. ${ }^{2} \mathrm{Az}$ elkövetett tett az, ami egyenlősít, s mely azonos büntetőjogi mércét teremt szegény és gazdag, nemes és paraszt között. A klasszikus büntetőjogi iskolának köszönhetően megszilárdult szabályt a 21. századi büntetőjogok is egyik alapelvükként tartják számon. Kétségtelen, hogy a büntetőjogi felelősség megállapításának középpontjában az elkövetett bủncselekmény áll, de a büntetést mindig konkrét személlyel szemben szabja ki a bíróság, és ennek a személynek szinte minden tulajdonsága komoly szempont lehet a büntetés meghatározásakor. ${ }^{3}$ A büntetés kiszabása során tehát a modern büntetőjogi rendszerekben sem tekinthetünk el attól, hogy részletesebb vizsgálat tárgyává tegyük, hogy ki is a konkrét büncselekmény elkövetője.

Annál is inkább, hiszen a büntetéskiszabás egyik deklarált feladata, hogy a kiszabott büntetés legyen tekintettel a büntetési célokra. A büntetés akkor tölti be leghatékonyabban a célját, ha a büncselekmény elkövetéséhez képest minél hamarabb, és az elkövetett tetthez, valamint az elkövető személyiségéhez igazítottan, vagyis az individualizáció elvét is szem elött tartva kerül kiszabásra. ${ }^{4}$ A büntetési célokra tekintettel történő büntetéskiszabás tehát nem képzelhető el az elkövető személyiségének a büntett által meghatározott körben és mélységben történő feltárása nélkül. Földvári szerint nagyon megkönnyítené a büntetéskiszabás felelősségteljes munkáját az elkövető személyiségének alapos ismerete. ${ }^{5}$

A terhelt személyi körülményeinek és személyiségének gondos vizsgálatához hozzátartozik előéletének alapos feltárása is, vagyis annak kiderítése, hogy követett-e el korábban büncselekményt, volt-e büntetve, s amennyiben igen, akkor hányszor, mikor, milyen bűncselekmény miatt, és végül, de nem utolsósorban, hogy milyen büntetési nemre ítélték. Ezek a tényezők ugyanis nagymértékben befolyásolhatják a kiszabott büntetést, hiszen a büntetlen előéletet többnyire enyhítő körülményként veszi figyelembe a bíróság, míg a bünismétlőkre, visszaesőkre - mint a társadalomra fokozott veszélyt jelentő elkövetőkre - szigorúbb büntetőjogi szabályok vonatkoznak. ${ }^{6} \mathrm{Az}$ elmúlt néhány évtized hazai büntetőjogi szakirodalma meglehetősen szűkölködik az elkövető előéletének alaposabb vizsgálatát végző tanulmányokban. Az 1970-es és 1980-as évekből igen gazdagnak mondható a téma kriminológiai

\footnotetext{
${ }^{1}$ GöRgÉNYI Ilona-GuLA József-HoRVÁTH Tibor-JAcsó Judit-LÉVAY Miklós-VÁRADı Erika: Magyar Büntetőjog, Általános Rész. Complex, Budapest, 2014, 68.

${ }^{2}$ Frossard, Serge: Quelques réflexions relatives au principe de la personnalité des peines. Revue de science criminelle et de droit pénal comparé, 1998/4, 704-705.

${ }^{3}$ RENDEKI Sándor: A büntetés kiszabása, Enyhítő és súlyosító körülmények. Közgazdasági és Jogi Könyvkiadó, Budapest, 1976, 155.

${ }^{4}$ PApAtheodoru, Théodore: La personnalisation des peines dans le noveau code pénal français. Revue de science criminelle et de droit pénal comparé, 1997/1, 15.

${ }^{5}$ FöldvÁRı József: A büntetés tana. Közgazdasági és Jogi Könyvkiadó, Budapest, 1970, 239.

${ }^{6}$ A francia büntetőjogi szakirodalom kifejezetten veszélyes bünelkövetőként tartja számon a visszaesőket. Lásd PRADEL, Jean: Droit pénal général. Cujas, Paris, 2016, 21édition, 623.
} 
feldolgozása, ${ }^{7}$ és ugyanebben az időszakban születtek utoljára a büntetőjogi szempontból ma is klasszikusnak számító, büntetéskiszabással (is) foglalkozó monográfiák, melyek természetesen érintették az elkövető előéletének kérdéskörét is. ${ }^{8} \mathrm{Az}$ utóbbi évtizedek büntetéskiszabással foglalkozó szakirodalma azonban a büntetőjogászok által méltatlanul elhanyagolt terület. A vonatkozó szakirodalom lajstromba szedése nem nehéz, hiszen kifejezetten hiányzik a kriminális előélet büntetéstani vizsgálata is. Ezért írásommal és kutatásommal a szakirodalom ebbéli adósságait is szeretném törleszteni azáltal, hogy ezúttal az elkövető előéletét, mint lehetséges büntetéskiszabási szempontot vizsgálom. Célom, hogy bemutassam a hatályos jogszabályi környezeten túl az elkövető előélete kapcsán kialakult és követett bírói gyakorlatot, és annak esetleges anomáliáira is felhívjam a figyelmet.

\section{A büntetlen előélet}

A büntetlen előélet a büntetés kiszabása során általában enyhítő körülmény. $A$ bíróság ebben az esetben azt a tényt értékeli a terhelt javára, hogy az még nem volt korábban bủncselekmény miatt elítélve. A bírói gyakorlatban a büntetlen előélet számos esetben szolgál a különös méltánylást érdemlő helyzetek hivatkozási alapjául is. Ennek megfelelően több ítéletben találkozunk vele a felfüggesztett szabadságvesztés kiszabásakor, ${ }^{9}$ a szabadságvesztés végrehajtási fokozatának enyhébb megállapításakor, ${ }^{10}$ a feltételes szabadság esetén a feles kedvezmény megítélésekor, ${ }^{11}$ vagy a büntetés enyhítésére vonatkozó szabályok alkalmazásakor. ${ }^{12}$

A büntetlen előélet azonban nem csupán egy személyes adat, hívja fel rá a figyelmet Rendeki Sándor, éppen ezért nem szabad önmagában az egyéb tényezőktől

\footnotetext{
${ }^{7}$ Meghatározó monográfia a témában: GöNczöL Katalin: A visszaeső bünelkövetők tipológiája. Közgazdasági és Jogi Könyvkiadó, Budapest, 1980. A témában megjelent tanulmányok nagy része is elsősorban az 1970-es 1980-as évekből, vagy még korábbról származik. Lásd például VERMEs Miklós: A visszaeső bủnözés kriminológiai vizsgálata. In: Gödöny József (szerk.): Kriminalisztikai Tanulmányok V. Közgazdasági és Jogi Könyvkiadó, Budapest, 1966, 68-104.; PATERA Antal-TAVASSY Tibor: A visszaeső bủnözés, mint a bűnözés sajátos újratermelődésének egyik alapja. In: Gödöny József (szerk.): Kriminológiai és Kriminalisztikai Tanulmányok 23. Közgazdasági és Jogi Könyvkiadó, Budapest, 1986, 123-184.; DÁNos Valér: A visszaeső bủnözés elleni harc időszerü kérdései. Belügyi Szemle, 1986/5, 39-44.

${ }^{8}$ RENDEKI: i. m.; FöldVÁRI: i. m., 357-370.; Bócz Endre: A személyi társadalomra veszélyesség. Közgazdasági és Jogi Könyvkiadó, Budapest, 1983.

9 BH 2001.4.151., BH 2000.3.93., BH 2000.1.11., Fővárosi İtélőtábla Bhar.281/2017/6., Fővárosi İtélőtábla 4.Bf.151/2018/7. Megjegyzést igényel továbbá, hogy hosszabb időn keresztül a korábbi Btk., az 1978. évi IV. törvény 89. $§(2)$ bekezdése az egy évnél hosszabb, de a két évet meg nem haladó szabadságvesztés esetén, különös méltánylást érdemlő esetben tette csupán lehetővé a büntetés felfüggesztését, mely kifejezetten indokolási kötelezettséget teremtett a jogalkalmazó számára. Ezt a rendelkezést a 2009. évi LXXX. törvény törölte el, és jelenleg is valamennyi két évet meg nem haladó szabadságvesztés végrehajtása próbaidőre felfüggeszthető, különös méltánylást érdemlő ok nélkül, de különösen az elkövető személyi körülményeire tekintettel.

${ }^{10}$ BH 2003.10.467., BH 1999.1.7., Szegedi Ítélőtábla Bf.III.8/2018/21.

$11 \mathrm{BH} 2000.2 .45$.

12 Kúria Bhar.III.561/2018/4., Debreceni İtélőtábla Bf.II.771/2017/38.
} 
elszakítva értékelni. ${ }^{13}$ Nyomatékos hangsúlyt kap akkor, ha a terheltnek kifogástalan életvezetése van. ${ }^{14}$ Abban az esetben azonban, ha az életvezetés is kifogásolható, például az elkövető züllött, alkoholista, csavargó, munkakerülő, agresszív életmódot folytat, a büntetlen előélet nyomatéka is csökken, sőt akár figyelmen kívül is hagyható. ${ }^{15} \mathrm{~A}$ büntetlen előélet nyomatéka annál nagyobb, minél idősebb az elkövető, vagyis a bíróság értékeli, hogy élete jelentős részét úgy élte le, hogy nem követett el büncselekményt, vagy ha el is követett, nem ítélték el. ${ }^{16}$

Az 56/2007. BK vélemény (továbbiakban 56. számú BKv.) iránymutatása szerint - az előbbiekből logikusan következtetve - a büntetlen előélet sem a fiatalkorú, sem a fiatal felnőttkorú esetén nem lehet enyhítő körülmény. Annak ellenére, hogy régi és következetesnek tekinthető felsőbb bírósági állásfoglalás rögzíti a fiatal felnőttkor és a büntetlen előélet egymást kizáró találkozását, úgy tűnik, hogy a bírói gyakorlat egyre gyakrabban felülvizsgálja ezt a kérdéskört is. A legtöbb megvizsgált ítéletben a bíróságok valóban tartják magukat a kúriai iránymutatáshoz. Azonban gyakran előfordul, hogy első fokon a bíróság enyhítő körülményként értékeli a büntetlen előéletet, és felsőbb bírósági szinten korrigálják az ítéleteket. Így ugyanabban az ügyben nem a büntetlen előélet, hanem csupán a fiatal felnőttkor bír enyhítő körülményként, avagy a fiatalkorú ügyében a büntetlen előélet nem lehet enyhítő körülmény. ${ }^{17}$ Találunk azonban ezzel ellentétes döntéseket is, amikor a bíróságok mindkét tényezőt enyhítő körülményként értékelik. ${ }^{18}$ A Fővárosi Ítélőtábla döntése szerint a Btk. 38. § (3) bekezdésének (a „feles” kedvezménynek) az indoka a vádlott fiatal felnőtt életkora, valamint az a tény, hogy korábban a törvénnyel összeütközésbe nem került, és azóta sem indult más büntetőeljárás ellene. ${ }^{19}$ Szintén a Fővárosi Ítélőtábla ítéletének indokolásában olvashatjuk, hogy „a vádlott fiatal felnőtt korára, az abból adódó befolyásolhatóságára és arra tekintettel, hogy a II.r. vádlottal folytatott kapcsolatának időszakától eltekintve a büntető törvénnyel összeütközésbe nem került, a büntetés súlyosítását nem tartotta indokoltnak". ${ }^{20} \mathrm{~A}$ vádlott büntetlenségét és fiatal felnőtt voltát az élet elleni cselekmény miatt kismértékben ugyan, de a javára értékelte a Budapest Környéki Törvényszék. ${ }^{21}$ Végül érdemes megemlíteni, hogy a fiatalkor és a büntetlen előélettel kapcsolatos következtetését illetően helytállónak, de indokolását tekintve egyértelműen aggályosnak tekinthető az Egri Törvényszék témával

\footnotetext{
${ }^{13}$ RendeKI: i. m., 197-198.

14 Debreceni Ítélőtábla Bf.I.348/2018/5., Fővárosi Ítélőtábla 16.Bf.168/2018/8.

${ }^{15} \mathrm{BH} 1977.8 .310$.

${ }^{16}$ Fővárosi Törvényszék B.1517/2017/59., Fővárosi Ítélőtábla 2.Bf.145/2018/8.

${ }^{17}$ BH 2005.246., Debreceni Ítélőtábla Bf.III.594/2016/13., Győri Ítélőtábla Bf.13/2017/7., Győri Ítélőtábla Bf.III.94/2017/7, Debreceni Ítélőtábla Bf.III.554/2016/4., Miskolci Törvényszék 8.B.24/2015/37., Debreceni Ítélőtábla Bf.I.912/2014/6., Fővárosi Ítélőtábla 5.Bf.356/2014/5., Szegedi Ítélőtábla Bf.I.309/2014/24, Nyíregyházi Törvényszék 1.B.720/2013/26., Szegedi Ítélőtábla Bf.I.341/2013/13, Szegedi Ítélőtábla Bf.I.84/2013/27., Fővárosi Ítélőtábla 2.Bf.6/2013/8., Debreceni Ítélőtábla Fkf.II.776/2017/5., Győri Ítélőtábla Fkf.II.57/2018/52., Fővárosi Törvényszék 23.Fkf.6055/2018/17., Szolnoki Törvényszék 9.Bf.314/2018/4., Szegedi Ítélőtábla Bf.IV.393/2018/18., Fővárosi Ítélőtábla 5.Bf.300/2017/14., Debreceni Ítélőtábla Bf.III.68/2018/10.

18 Még a korábbi bírói gyakorlatból lásd BH 1976.7.290., BH 1992.4.221.

${ }^{19}$ Fővárosi Ítélőtábla Bf.124/2015/9.

${ }^{20}$ Fővárosi Ítélőtábla Bf.165/2015/19.

${ }^{21}$ Budapest Környéki Törvényszék B.23/2015/11.
} 
kapcsolatos gondolata, hiszen az statisztikai adatokkal egyáltalán nem támasztható alá. Ismeretes ugyan, hogy a 20 éves vádlott esetén az eddigi büntetlen előéletét enyhítő körülményként nem lehet értékelni, azonban „figyelemmel a fiatalkorúak körében rohamosan terjedő egyre nagyobb számban elkövetett büncselekményekre, ez a nézet kezd meghaladottá válni és a bíróság álláspontja szerint a vádlott esetében addigi kifogástalan életvezetését a javára lehet értékelni”. ${ }^{22}$

A büntetéskiszabási körülmények a társadalom fejlödésével, az erkölcsi, etikai mérce átértékelődésével, de még a bűnözés alakulásával is változhatnak. Ezért is indokolt ezeket a körülményeket időről időre felülvizsgálni, és nem tekinthető hibának, ha egy eddig töretlenül követett, de mára meghaladottá vált bírói gyakorlatot átalakít az új szemlélet. Úgy tűnik, hogy a bírák igazságérzete konkrét esetekben megkívánja a fiatalkor, fiatal felnőttkor és a büntetlen előélet újragondolását is. Egyes bíróságok egyértelműen afelé tendálnak, hogy a két körülményt igyekeznek elválasztani, és külön tényezőként kezelni. A fiatal felnőttkort elsősorban azért értékelik a büntetéskiszabás során, mert a felnőttkor küszöbén álló vádlott személyiségének fejlettségi szintje nagyobb hasonlóságot mutat a fiatalkorú elkövetőkével. ${ }^{23}$ A fiatal felnőtt még kiforratlan személyiség. Büncselekményét már felnőttkorban követte el, így a hatályos büntetőjogi rendelkezések alapján a felnőttekre vonatkozó szabályokat fogja rá alkalmazni a bíróság azzal, hogy a fiatal életkor csupán egy lesz a figyelembe vehető büntetéskiszabási körülmények között. A büntetlen előélet ezzel szemben azt a szempontot jelenti, hogy a vádlott eddigi életútja makulátlan, még nem került összeütközésbe a törvénnyel, de legalábbis büncselekmény miatt nem ítélték el. Nyilvánvalóan és helyesen nagyobb ennek a nyomatéka, amennyiben az elkövető élete nagy részét büntetlenül élte le, de a magam részéről nem látom akadályát annak, hogy egy fiatal felnőtt esetén, a még kiforratlan személyisége mellett is enyhítő körülményként értékeljék a büntetlen előéletet, figyelembe véve azt a tényt is, hogy a fiatalok (fiatalkorúak és fiatal felnőttek) kriminalitási aránya az összbünözésen belül igen magas. ${ }^{24}$

Speciális a büntetlen előélet megítélése a hivatalos személy elkövető esetén is. A bủncselekményt elkövető hivatalos személyek javára a büntetlen előélet enyhítő körülményként elvileg csak akkor vehető figyelembe, ha a büncselekmény nincs

\footnotetext{
22 Egri Törvényszék 11.B.599/2013/6.

${ }^{23}$ A fiatal felnőttkor problémaköréről, az önálló büntetőjogi kategóriaként történő szabályozás megteremtésének szükségességéről, valamint a gyakorlatról lásd részletesen CsúRı András: $A$ fiatal felnőttkor, mint büntetőjogilag releváns életszakasz. Doktori értekezés, Szegedi Tudományegyetem, 2008; CsúRI András: Fiatal nagykorú vagy fiatal felnőtt? Egy fogalmi újítás szükségessége, aktualitása és dogmatikai jelentősége. Rendészeti Szemle, 2007/9, 46-59.; CsúRI András: A fiatal felnőtt életszakasz büntetőjogi szabályozásának lehetőségei. Magyar Jog, 2008/4, 202-215.; CsúRI András: A fiatal felnőtt életkor szabályozásának alapkérdései a magyar büntetőjogban. Rendészeti Szemle, 2008/7-8, 49-71. A fiatal felnőttkor mint büntetéskiszabási körülmény gyakorlati szempontból történő megközelítését lásd PÁPAI-TARR Ágnes: Egy büntetéskiszabási tényező: a fiatal felnőttkor. Miskolci Jogi Szemle, 2019/1, 65-78.

${ }^{24}$ Ahogy azt már fentebb is említettem, a fiatalkorúak bűnözése nem mutat ugyan évről évre növekvő tendenciát, de az tény, hogy a Bünügyi Statisztikai Rendszer adatai alapján az elmúlt években 25 és $30 \%$ között mozog az összbűnözésen belül a fiatalkorúak és a fiatal felnőttek együttes aránya, s ez az adat egy közel állandósult tendenciát jelez. https://bsr.bm.hu/ (2019. 12. 05.).
} 
összefüggésben a hivatalos minőséggel. ${ }^{25}$ Hivatali büncselekmények elkövetése esetén tehát a hivatalos személy javára a büntetlen előélet egyáltalán nem értékelhető. ${ }^{26} \mathrm{Az}$ anonim bírósági határozatok között kutakodva ebben a tekintetben is találunk a főszabállyal ellentétes döntéseket, ahol a hivatali büncselekmény elkövetése ellenére mégis megemlítésre kerül, hogy a „büntetlen” előéletü vádlottal szemben nem volt indokolt végrehajtandó szabadságvesztés-büntetés kiszabása. ${ }^{27}$ Tehát a vádlott személyi körülményeit azzal egészíti ki a másodfokú bírósági tanács, hogy a vádlott büntetlen előéletü. ${ }^{28} \mathrm{~A}$ hivatalos személy vádlott ügyében - mivel a büntetlen előélet alkalmazási feltétel - legfeljebb az a körülmény értékelhető enyhítőként, hogy a törvénnyel még sohasem került összeütközésbe. Számos bírósági döntésből már-már az a téves következtetés vonható le, mintha ez a szabály egyáltalán nem is létezne, és csak a másodfokú döntésben kerül korrigálásra, hogy nem a vádlott büntetlen előélete képez enyhítő körülményt, hanem csupán a vádlott eddigi hibátlan életvezetésére lehet hivatkozni. ${ }^{29}$ Nincs azonban akadálya annak, hogy a hivatalos személy vádlott ügyében a hivatali minőségével összefüggésbe nem hozható büncselekmény esetén a büntetlen előéletét enyhítő körülményként értékelje a bíróság. ${ }^{30}$ Ugyanígy nem vehető figyelembe a büntetlen előélet annak javára, aki a bủncselekményt olyan beosztás felhasználásával követte el, amelyben a büntetlen előélet alkalmazási feltétel (például ügyvéd, ügyvédjelölt, egyetemi oktató stb.).

A büntetlen előélet szintén jelentőségét veszti, ha sorozatosan, folyamatosan, hosszabb időn át követett el az elkövető bủncselekményeket, vagy éppen több büntetőeljárás is folyamatban van ellene. ${ }^{31} \mathrm{~A}$ büntetőeljárás hatálya alatti elkövetésröl az 56. számú BKv. úgy foglal állást, hogy ha az elkövető az ellene folyamatban levő büntetőeljárás hatálya alatt, erről tudva követi el a büncselekményt, és ebből - az előző eljárás eredményétől függetlenül - a személyének fokozott veszélyességére lehet következtetni, a büntetőeljárás hatálya alatt történt bünelkövetés súlyosító körülmény. Azonban találunk ezzel ellentétes, de meggyőző érvelést is, amikor a Debreceni Ítélőtábla döntése szerint, a büntetlen előéletet nem rontja le a büntetőeljárás hatálya alatti elkövetés, figyelemmel az ártatlanság vélelmére. ${ }^{32}$

A büntetlen előélet nyomatéka csökken a legsúlyosabb büntettek elkövetőinek esetében, amikor a bünre indító motívumok végletes túlsúlyára lehet következtetni. Ez utóbbi körülményből az következik, hogy minél jelentősebb egy büncselekmény

\footnotetext{
${ }^{25}$ BH 2001.8.360., Szegedi Ítélőtábla Bf.33/2018/6.

${ }^{26}$ Fővárosi İtélőtábla Katonai Tanácsa 6.Kbf.26/2018/5., Fővárosi Ítélőtábla Katonai Tanácsa 6.Kbf.88/2017/30., Fővárosi Ítélőtábla Katonai Tanácsa 6.Kbf.65/2017/6., Kúria Bhar.I.1826/2017/7.

${ }^{27}$ Fővárosi Ítélőtábla Katonai Tanácsa 6.Kbf.27/2017/9.

${ }^{28}$ Fővárosi İtélőtábla Katonai Tanácsa 6.Kbf.30/2018/8., Fővárosi Ítélőtábla Katonai Tanácsa 6.Kbf.58/2018/19., Fővárosi Ítélőtábla Katonai Tanácsa 6.Kbf.1/2017/7.

${ }^{29}$ Fővárosi Ítélőtábla Katonai Tanácsa 6. Kbf.16/2018/6., Fővárosi Ítélőtábla Katonai Tanácsa 6.Kbf.15/2018/6., Fővárosi Ítélőtábla Katonai Tanácsa 6.Kbf.13/2017/9., Fővárosi Ítélőtábla Katonai Tanácsa 6.Kbf.19/2017/6., Fővárosi Ítélőtábla Katonai Tanácsa 6.Kbf.14/2017/5., Fővárosi Ítélőtábla Katonai Tanácsa 6.Kbf.2/2017/6., Fővárosi Ítélőtábla Katonai Tanácsa 6.Kbf.159/2016/5.

30 Fővárosi Ítélőtábla Katonai Tanácsa 6.Kbf.45/2018/8.

31 Fővárosi Ítélőtábla 3.Bf.31/2018/7.

${ }^{32}$ Debreceni İtélőtábla Bf.III.71/2018/10. Ehhez hasonló érveléssel találkozunk még: Győri Ítélőtábla Bf.III. $121 / 2017 / 4$.
} 
tárgyi súlya, a büntetlen előélet mint enyhítő körülmény jelentősége arányosan csökken. ${ }^{33} \mathrm{Nem}$ vette figyelembe például a bíróság a büntetlen elöéletet enyhítö körülményként egy fiatal lány sérelmére, nyílt utcán, útonálló módon és kiemelkedő durvasággal lezajló szemérem elleni erőszak esetén, ami a jelenleg hatályos Btk. szerint szexuális erőszak minősített esetének felelne meg. ${ }^{34} \mathrm{~A}$ bírói gyakorlat szerint az életellenes büncselekményeknél a büntetlen elöélet nyomatéka minimális. ${ }^{35}$

A büntetlen előélet enyhítő körülményként történő figyelembevétele nem tekinthető tehát automatikusnak. Az elkövetett bűncselekmény tárgyi súlyára vagy éppen az elkövető valamely személyes tulajdonságára, illetve egy adott élethelyzetre tekintettel enyhítő körülményként egyáltalán nem vehető figyelembe, vagy legalábbis nyomatéka lényegesen csökken.

\section{Egyes bünismétlő kategóriák és azok jogkövetkezményei a magyar büntetöjogban}

A magyar büntetőjog a bủnismétlőket öt kategóriába sorolja. Vannak visszaesőnek nem minősülő bűnismétlők, vagy egyszerű bűnismétlők, visszaesők, különös és többszörös visszaesők, valamint erőszakos többszörös visszaesők. A visszaeső bủnelkövetőkkel szemben a Btk. a kemény kéz büntetőpolitikáját érvényesíti, és számos szigorítást tartalmaz. ${ }^{36} \mathrm{~A}$ terheltnek természetesen nem mindegy, hogy melyik minősítés alapján kerül sor vele szemben a büntetés kiszabására. Hiába definiálja a Btk. a különböző típusú visszaesői kategóriákat, ezeknek a szabályoknak a gyakorlatban való alkalmazása és értelmezése sokszor nem egyszerủ feladat, és előfordul, hogy valamelyik minősítés megállapítására tévesen vagy egyáltalán nem kerül sor. ${ }^{37}$ A téves minősítés pedig törvénysértő büntetéskiszabást eredményezhet ${ }^{38}$ Érdemes azonban megjegyezni, hogy a visszaesői minőség megállapítása elsősorban büntetéskiszabási, és nem minősítési kérdés. A Kúria az erőszakos többszörös viszszaesőkkel kapcsolatban szögezi le, hogy ennek a minősítésnek a megállapítása vagy éppen ennek elmaradása nem része a bủncselekmény minősítésének, hanem büntetéskiszabást érintő rendelkezés, ezért téves megállapítása vagy elmulasztása a bűncselekmény téves minősítése címén felülvizsgálati okot sem képez, ${ }^{39}$ legfeljebb a „büntetőjog más szabályának megsértése” címén képezhet felülvizsgálati okot, amennyiben emiatt törvénysértő büntetés kiszabására került sor. ${ }^{40}$ Logikusan

${ }^{33}$ Győri İtélőtábla Bf.II.88/2018/8., Győri İtélőtábla Bf.II.96/2017/6.

${ }^{34} \mathrm{BH}$ 1992.10.620.

${ }^{35}$ Fővárosi Ítélőtábla 4.Bf.190/2018/6.

${ }^{36}$ Btk. Miniszteri Indokolása.

${ }^{37}$ Kúria Bfv.l.1522/2017/6., Kúria Bfv.II.873/2018/5.

${ }^{38}$ Például többszörös visszaesőt visszaesőként kezelve a bíróság felfüggesztett szabadságvesztést szabott ki, holott a felfüggesztett szabadságvesztés a többszörös visszaesővel szemben kizárt. Kúria Bfv. III.189/2018/12.

${ }^{39} \mathrm{BH}$ 2013.2.43.

${ }^{40}$ A korábbi Be. szabályai alapján lásd: 1998. évi XIX. törvény 416. §. (1) bekezdés b) pont „büntetőjog más szabályának megsértése miatt törvénysértő büntetést szabtak ki, vagy törvénysértő intézkedést alkalmaztak", lásd továbbá: $\mathrm{BH} 2015.11 .457$. 
következik az is, hogy pusztán a különös visszaesői minőség téves megállapítása, amennyiben ez a büntetéskiszabást nem befolyásolta, szintén nem képezhet felülvizsgálati okot. ${ }^{41} \mathrm{Az}$ új Be. az eddigi bírói gyakorlaton annyiban változtat, hogy az ún. egyszerüsített felülvizsgálati eljárás lefolytatásának van helye a 671. § 16. pont alapján, ha az elítélt visszaesői minőségéről nem rendelkezett vagy tévesen rendelkezett a bíróság.

\subsection{Visszaesőnek nem minősülő bünismétlők}

A Btk. maga sem rendelkezik a korábban már bűncselekményt megvalósító személyek valamennyi csoportjáról, hiszen a bűnismétlők közül csak a különböző viszszaesői kategóriákat határozza meg. Így negatíve meghatározható fogalomként él a büntetőjogban az egyszerü bünismétlő fogalma, hiszen ennek kell tekinteni azokat a bünelkövetőket, akik követtek már el korábban büncselekményt, de valamilyen oknál fogva nem minősülnek visszaesőnek. A magyar büntetőjogban a büntetett előélethez füződő hátrányok alóli mentesülés csak a büntetőjogon kívüli jogkövetkezményekre vonatkozik. Ez azt jelenti, hogy amennyiben valaki valamikor is büncselekményt követett el, majd emiatt elítélték, és a bünügyi nyilvántartásba bekerült, akkor büntetőjogi szempontból onnan soha nem kerül törlésre..$^{42}$ Amennyiben egy elkövető nem minősül visszaesőnek, mert például korábban gondatlan bűncselekmény miatt ítélték el, vagy több mint 3 év telt el a korábbi büntetés kitöltése és az újabb büncselekmény elkövetése között, avagy korábban nem végrehajtandó szabadságvesztésre ítélték, akkor is bünismétlőnek minősül. Az egyszerü vagy visszaesőnek nem minősülő bünismétlést a bíróság a büntetés kiszabása körében eltérő nyomatékú súlyosító körülményként értékeli. Ha a büntetett előéletű elkövető nem visszaeső, de többször volt büntetve, akkor ez utóbbi tény szintén súlyosító körülmény lehet. ${ }^{43}$ Növeli a súlyosító körülmény nyomatékát az is, ha a bủncselekmények között rövidebb idő telt el, ha korábban is azonos vagy hasonló büncselekmény miatt történt az elítélés. ${ }^{44}$ Ugyanakkor az 56. számú Bkv. szerint nem indokolt a korábbi elítélést súlyosító körülményként értékelni, ha kisebb tárgyi súlyú büncselekményt követett el az elkövető, és a bűncselekmények elkövetése között már hosszabb idő eltelt. Fokozott a büntetett előélet nyomatéka, ha a sorozatos elítélésekből, az elkövető életviteléből és az újabb bủnelkövetésből a bủnözői életmódra lehet következtetni. ${ }^{45}$

A bírói gyakorlatban meglehetősen színes képet kapunk arról is, hogy a büntetett előélet mellett a fiatal felnőttkor figyelembe vehető-e, mint enyhítő körülmény. Ebben

${ }^{41} \mathrm{BH}$ 2014.12.525. Ha a bíróság a terhelt különös visszaesői minőségét tévesen állapította ugyan meg, de annak büntetési tételkeret-emelő hatását nem használta ki, pusztán a különös visszaesés kimondását sérelmezve a felülvizsgálat a törvényben kizárt [1978. évi IV. törvény a Büntető Törvénykönyvről 97 . § (1) bekezdés]. Lásd még BH 2004.5.199.

42 Ettől függetlenül az erkölcsi bizonyítványa tiszta lehet és a büntetőjogon kívüli hátrányok alól mentesül. Az elítéléshez füződő hátrányos következmények alóli mentesítés szabályait lásd: Btk. 97-104. §.

${ }^{43}$ Fővárosi Törvényszék 15.B.1153/2017/23.

${ }^{44}$ Az ilyen visszaesőnek nem minősülőt speciális bűnismétlőként említi a Pécsi Ítélőtábla Bf.III.15/2018/6.

45 Kúria Bfv.l.544/2018/9. 
a kérdésben az 56. számú BKv.-ban iránymutatást egyáltalán nem találunk. Így aztán a bírói gyakorlatból szemezgetve találunk példát arra is, hogy a bíróság a büntetett előélet mellett a fiatal felnőttkort enyhítő körülményként értékelte. ${ }^{46}$ Azonban a Pécsi Ítélőtábla döntései közt olvashatjuk, hogy „mellőzni kellett az enyhitö körülmények köréből a (terhelt) fiatal felnőtt voltára történő utalást, hiszen az csak abban az esetben értékelhetö enyhitő körülményként, ha az a büntetlen elöélettel társul". ${ }^{47}$ Ugyanezen indok alapján több olyan döntést is találunk, ahol a bíróság eltekintett a fiatal felnőttkor enyhítő körülményként történő figyelembevételétöl. ${ }^{48}$ Ezzel ellentétben a Miskolci Törvényszék ítélete alapján a fiatal felnőttkor csekély fokban enyhítö, ha például a vádlott büntetett előéletü. ${ }^{49} \mathrm{~A}$ Fővárosi Ítélőtábla döntésében, a nemzetközi tendenciákat is szem előtt tartva, hivatkozva az Európa Tanács R. (2003) 20. sz. ajánlására, ${ }^{50}$ a fiatal felnőttkornak enyhítő hatást tulajdonított annak ellenére, hogy a vádlott már volt büntetve.$^{51}$ Úgy tủnik tehát, hogy a fiatal felnőttkor és a büntetlen előélet találkozása mellett a fiatal felnőttkor és a büntetett előélet együttes előfordulása is vitákat kiváltó kérdés, és ebben a tekintetben sem egységes a bírói gyakorlat.

\subsection{Visszaesők}

A Btk. igen pontosan határozza meg, hogy kit tekintünk a magyar büntetöjogban visszaesőnek. ${ }^{52}$ Ennek alapján négy konjunktív feltételnek kell teljesülnie ahhoz, hogy a visszaesés megállapítható legyen. Elöször is a visszaeső legalább két büncselekményt kell, hogy elkövessen, ráadásul a törvény mindkét alkalommal a szándékos elkövetést követeli meg. Gondatlanságból elkövetett bűncselekmények tehát nem alapozhatják meg a visszaesői minősítést, még akkor sem, ha korábban már több ízben történt gondatlan büncselekmény(ek) miatti elítélés.

Harmadsorban jelentősége van az első bủncselekmény miatt kiszabott szankciónak, hiszen az első szándékos büncselekmény miatt az elkövetőt végrehajtandó szabadságvesztésre kell hogy ítéljék. Vagyis az első büncselekmény miatt kiszabott felfüggesztett szabadságvesztés, ${ }^{53}$ elzárás, közérdekű munka vagy pénzbüntetés szintén nem adnak alapot a visszaesői minősítés megállapítására. A visszaeső fogalmának negyedik fontos összetevője egy meghatározott idő, melyen belül a büncselekmények elkövetése történik. Ebben a tekintetben a Btk. rendelkezései nem teljesen egyértelműek, hiszen az első büncselekmény miatt kiszabott büntetés

${ }^{46} \mathrm{BH} 2003.271$.

47 Pécsi Ítélőtábla Fkf.I.2/2017/16.

${ }^{48}$ Fővárosi Ítélőtábla 5.Bf.102/2015/7, Szegedi İtélőtábla Bf.I.83/2014/11., Fővárosi Ítélőtábla 5.Bf.208/2011/11., Fővárosi Ítélőtábla 1.Bf.36/2017/12, BH 2004.353.

49 Miskolci Törvényszék B.49/2016/24.

${ }^{50}$ Az Európa Tanács R 2003 (20). számú ajánlása a fiatalkorú bűnelkövetőkre vonatkozó igazságszolgáltatási rendszerről.

51 Fővárosi Ítélőtábla 1.Bf.116/2013/34.

52 Btk. 459. § (1) bekezdés 31. pont.

${ }^{53}$ A felfüggesztett szabadságvesztés még abban az esetben sem alapozza meg a visszaesői minőséget, ha a felfüggesztett szabadságvesztés végrehajtását utólag elrendelik. $\mathrm{BH}$ 2016.6.132., $\mathrm{BH} 2015.12 .498$., $\mathrm{BH}$ 2015.10.415., BH 2014.4.150. 
kitöltése vagy végrehajthatóságának megszűnésétől számított 3 évet jelöli meg a törvény. E jogszabályhely nyelvtani értelmezése arra engedne következtetni, hogy a 3 éves határidő számításának kezdő időpontja az a nap, amikor a végrehajtandó szabadságvesztését az elítélt ténylegesen kitöltötte, vagy a feltételes szabadságra bocsátás próbaideje eredményesen eltelt. Ebben az esetben azonban teljesen logikátlanul nem alapozná meg a visszaesői minőséget, ha valaki a büntetés-végrehajtási intézetben vagy a feltételes szabadságra bocsátásának ideje alatt követne el szándékos bủncselekményt. A bírói gyakorlat e tekintetben már több ízben is állást foglalt: a visszaesés megállapíthatóságához a törvény által megkívánt időtartam a korábbi szándékos büncselekmény miatt jogerős, végrehajtandó szabadságvesztésre ítélés időpontjával kezdődik, és a büntetés kitöltésétől vagy végrehajthatósága megszűnésétől számított három évig tart. ${ }^{54} \mathrm{Az}$ ez alatt az időszak alatt megvalósított szándékos büncselekmény elkövetője minősül tehát visszaesőnek. A visszaesői minőség megállapításának az sem akadálya, ha a köztársasági elnök végrehajtási kegyelemben részesíti az elítéltet; ebben az esetben a 3 éves időtartamot a kegyelmi határozat napjától kell számítani. ${ }^{55}$

Amennyiben a törvényi definíció értelmében megállapítást nyer, hogy az elkövető visszaeső, akkor az 56. számú BKv. szerint ezt súlyosító körülményként értékeli a bíróság. Ezen túl a visszaeséshez a jogalkotó is számos negatív jogkövetkezményt füz. Amennyiben a visszaesőt vétség miatt vonják felelősségre, és végrehajtandó szabadságvesztésre ítélik, akkor börtön fokozatban kell végrehajtani a büntetést. Feltételes szabadságra csak akkor bocsátható, amennyiben a kiszabott büntetésének a háromnegyed részét kitöltötte.$^{56}$ Feltételes szabadságra bocsátása és végrehajtásában felfüggesztett szabadságvesztésre ítélése esetén kötelezően pártfogó felügyelet alatt áll. A visszaeső ezenkívül nem részesülhet a próbára bocsátás és a jóvátételi munka intézkedések kedvezményeiben sem. A bíróság a visszaesői minőséget megalapozó elítélésen túli büntetettséget további súlyosító körülményként értékelheti. ${ }^{57}$

Az anonim bírósági határozatok között akadt olyan, amelyik szerint a visszaesői minőség nem értékelhető a vádlott terhére, ugyanis azt a törvényszék már értékelte akkor, amikor úgy rendelkezett, hogy a vádlott a kiszabott szabadságvesztésből annak háromnegyed részének kitöltését követő napon bocsátható feltételes szabadságra. ${ }^{58} \mathrm{Ez}$ az érvelés azonban véleményem szerint téves. A Btk. a visszaesőkkel szemben történő büntetés kiszabása során nem írja elő szigorított büntetési tétel alkalmazását, így semmi nem zárja ki, hogy a vádlott visszaesői minőségét a büntetéskiszabás során súlyosító körülményként értékelje a bíróság. A jogalkotó által meghatározott szigorítás, miszerint a visszaeső a szabadságvesztés háromnegyedének letöltése után bocsátható feltételes szabadságra, a büntetéskiszabástól függetlenül alkalmazandó rendelkezés. A bíróság fenti érvelésének megfelelően

\footnotetext{
${ }^{54}$ BH 2018.3.75., BH 2018.10.273., BH 2015.5.194., BH 2005.199.

${ }^{55} \mathrm{BH} 1987.6$.

${ }^{56}$ Amennyiben nem visszaeső, akkor kétharmad rész kitöltése után feltételes szabadságra bocsátható. Lásd Btk. 38. § (2) bekezdés a) pont.

10057 Debreceni Ítélőtábla Bf.I.400/2018/47.

58 Szegedi Ítélőtábla Bf.III.316/2018/23.
} 
a különös és többszörös visszaesővel szemben, akire ráadásul szigorított büntetéskiszabási szabályok vonatkoznak, ${ }^{59}$ már nem is lehetne alkalmazni a háromnegyedes szabályt, hiszen a különös és többszörös visszaesői minőséget egyszer már értékelte a büntetéskiszabás során a bíróság. A helyes értelmezés tehát az, hogy a Btk.-ban a visszaesőkre meghatározott szigorítások együttesen, egymás mellett is alkalmazhatók.

\subsection{A különös és a többszörös visszaesők}

A különös visszaeső az a visszaeső, aki mindkét alkalommal ugyanolyan vagy hasonló bűncselekményt követett el. ${ }^{60} \mathrm{~A}$ különös visszaesőnél tehát a jogalkotó a bủnelkövető fokozott társadalomra veszélyességét abban látja, hogy mindkét alkalommal azonos, de legalábbis hasonló bủncselekmény elkövetésére kerül sor. ${ }^{61}$

Az ugyanolyan bủncselekményen az azonos törvényi tényállásba ütköző cselekményeket értjük, és nincs jelentősége annak, hogy alap- vagy minősített eseti tényállásról, előkészületről, kísérletről vagy éppen befejezett büncselekményről van-e szó. ${ }^{62}$ Ahol a törvény a különös visszaesésnek jelentőséget tulajdonít, a Btk. maga rögzíti, hogy melyek az adott bűncselekményhez képest a hasonló bűncselekmények. ${ }^{63}$

A többszörös visszaesői kategória megalkotásának célja az volt, hogy kellő szigorral lehessen fellépni azokkal szemben, akik sorozatosan követnek el búncselekményeket. Többszörös visszaeső az, akit a szándékos büncselekmény elkövetését megelőzően visszaesőként végrehajtandó szabadságvesztésre ítéltek, és az utolsó büntetés kitöltésétől vagy végrehajthatósága megszűnésétől, a szabadságvesztéssel fenyegetett újabb büncselekmény elkövetéséig három év még nem telt el. ${ }^{64}$ A többszörös visszaeső tehát immár a harmadik szándékos büncselekményt követi el. A többszörös visszaesői minőség azonban csak abban az esetben állapítható meg, ha korábban a bíróság kimondottan megállapította visszaesői minőségét,

${ }^{59}$ Btk. 89. §. Lásd továbbá a tanulmány 2.3. alpontját.

${ }^{60}$ Btk. 459. § (1) bekezdés 31. a) pont.

${ }^{61}$ Nagyon sokáig a magyar büntetőjogban csak az azonos vagy hasonló bủncselekmény elkövetése alapozta meg a visszaesői minősítés megállapíthatóságát. Lásd BALLA Lajos: Adalékok a visszaesők megítéléséhez a magyar jogban. Bírák Lapja, 2011/1-2, 114-120. Még a szocialista Btk. idején is, amikor már a Btk. Általános Része határozta meg a visszaeső fogalmát, még mindig élt a szabály, hogy csak a hasonló bűncselekmények elkövetőit tekintették visszaesőnek, lásd 1961. évi V. törvény a Magyar Népköztársaság Büntető Törvénykönyvéről 115. §.

$62 \mathrm{BH}$ 2013.2.51.

${ }^{63}$ A Btk. Különös Része az alábbi büncselekmények esetén rendelkezik a különös visszaesőkröl: emberölés Btk. 160. $\S(2)$ bekezdés $h$ ) pont, rendbontás Btk. 340. $\S(3)$ bekezdés $d$ ) pont, erőszakos vagyon elleni bűncselekmények Btk. 369. §, vagyon elleni büncselekmények Btk. 383. §d) pont, szellemi tulajdonjog elleni bűncselekmények Btk. 388/B §, költségvetési csalás Btk. 396. § (9) bekezdés $c$ ) pont. Például az emberölés kapcsán a különös visszaesést minösítő körülményként találjuk, ezért a Btk. 160. § (6) bekezdése tartalmazza, hogy a különös visszaesés szempontjából melyek az emberöléshez hasonló bűncselekmények. llyennek minősül például az erős felindulásban elkövetett emberölés, népirtás, az emberrablás súlyosabban minősülő esete, terrorcselekmény, jármű hatalomba kerítése satöbbi.

${ }^{64}$ Btk. 459.§ (1) bekezdés 31. b) pont. 
és mint visszaesőt ítélte el a bủnelkövetőt. Amennyiben a bíróság elmulasztotta a visszaesői minőség megállapítását, holott annak törvényi feltételei fennálltak, akkor nem állapítható meg a többszörös visszaesői minőség sem. ${ }^{65}$ Ugyanezen indok alapján nem állapítható meg a többszörös visszaesés (erőszakos többszörös viszszaesés sem), amennyiben külföldi ítélet magyarországi elismerésekor a külföldi bíróság nem állapította meg ítéletében, hogy a vádlott visszaeső.

Sok esetben a terhelt többszörös visszaesői minősítésének a megállapítása csupán néhány hónapon vagy héten múlik. Ezeket az élethelyzetekkel szükségképpen együtt járó igazságtalanságokat a gyakorlat igyekszik figyelembe venni, és a büntetéskiszabás körében némileg kompenzálni. A bírói gyakorlatban találunk példát arra is, hogy nyomatékos súlyosító körülményt jelentett adott esetben, amikor csak pár hónapon múlott, hogy a terhelt nem különös vagy többszörös visszaesőként állt a bíróság előtt. ${ }^{66}$

A különös visszaesőkkel szembeni szigorúbb fellépés kétféleképpen jelenhet meg a magyar büntetőjogban. Egyrészt a Btk. Különös Részében szerepelhet a különös visszaesés mint minősítő körülmény, másrészt a Btk. Általános Része szigorított büntetéskiszabási szabályt állapít meg ezzel az elkövetői kategóriával szemben. Amennyiben a különös visszaesés minösítö körülmény, akkor a kétszeres értékelés tilalmának megfelelően már az Általános Rész szigorított büntetéskiszabási szabálya nem alkalmazható ${ }^{67} \mathrm{~A}$ Btk. Általános Része által szabályozott jogkövetkezmény, hogy a különös és a többszörös visszaesővel szemben - ha e törvény másként nem rendelkezik - az újabb büncselekmény büntetési tételének felső határa szabadságvesztés esetén a felével emelkedik, de nem haladhatja meg a huszonöt évet. ${ }^{68}$ Ez azt jelenti, hogy amennyiben a bíróság megállapítja például egy rablás alapesetének búncselekményében, hogy az elkövető különös visszaeső, akkor a 8 éves büntetési tételének a felső határa 12 évre emelkedik. A különös visszaesővel szemben a büntetés enyhítésére csak kivételesen, különös méltánylást érdemlő esetben kerülhet sor. A különös visszaeső ezenkívül természetesen visszaesőnek minősül, ezért a fent ismertetett és a visszaesőkre vonatkozó szigorúbb szabályokat ezen elkövetőkre is értelemszerüen alkalmazni kell.

A magyar büntetőjogban a többszörös visszaeső, aki immár harmadjára követett el szándékos bűncselekményt, a Btk. Általános Részében meghatározott szigorított szankció kiszabására számíthat. Vagyis a többszörös visszaesés - ellentétben a különös visszaeséssel - nem lesz soha minősítö körülmény. A kiszabott büntetés szigorítását illetően azonos szabályok vonatkoznak a különös és a többszörös viszszaesőkre, vagyis, amennyiben a többszörös visszaesés megállapítható, akkor a szabadságvesztés esetén a büncselekmény büntetési tételének felső határa a felével emelkedik, de nem haladhatja meg a 25 évet.

Ezenkívül a Btk. Általános Része még számos szigorítást tartalmaz erre az elkövetői kategóriára is. Amennyiben a többszörös visszaesőt 2 évi vagy azt meghala-

${ }^{65} \mathrm{BH}$ 1993.6.334.

${ }^{66}$ Győri İtélőtábla Bf.I.133/2017/7., Fővárosi İtélőtábla 5.Bhar.104/2015/10.

${ }^{67}$ Az emberölésnél nem lehet például a különös visszaesés speciális büntetéskiszabási szabály és súlyosító körülmény sem, hiszen minősítő körülményről van szó. Lásd például Szegedi İtélőtábla Bf.III.474/2017/18.

${ }^{68}$ Btk. 89. § (1) bekezdés. 
dó tartamú szabadságvesztésre ítélik, akkor a legszigorúbb büntetés-végrehajtási fokozatban, fegyházban kell a szabadságvesztést végrehajtani. ${ }^{69}$ Ez utóbbi esetben, amennyiben a többszörös visszaeső fegyház fokozatban tölti a szabadságvesztés büntetését, akkor kizárt a feltételes szabadságra bocsátása. ${ }^{70}$ Ezenkívül kizárt a szabadságvesztés-büntetés végrehajtásának a felfüggesztése is. ${ }^{71}$ Ezekből a szabályokból összességében arra következtethetünk, hogy a többszörös visszaesővel szemben egészen nagy a valószínűsége, hogy végrehajtandó szabadságvesztést fog a bíróság kiszabni, és sok esetben azt teljes egészében le kell majd tölteni, tekintettel a felével emelt büntetési tételekre is. A többszörös visszaesöre is igaz, hogy a büntetés csak különös méltánylást érdemlő esetben enyhíthető.

Érdekes helyzetet teremt, ha a többszörös visszaeső egyben különös visszaeső is. Kérdés, hogy a két körülmény értékelhetö-e egyszerre, és ez nem ütközik-e a ne bis in idem elvbe. Érdekes elméleti és gyakorlati kérdés továbbá, hogyan történjen ebben az esetben a büntetéskiszabás. A két különböző visszaesői kategóriának a megteremtéséből logikusan az következik, hogy a jogalkotó két különböző szempontot vett figyelembe, amikor külön szabályozta a fogalmakat. Különös visszaesönél az ugyanolyan vagy hasonló büncselekmény ismételt elkövetését értékeli szigorúbban a jogalkotó, míg a többszörös visszaesőnél az elkövetett büncselekmények számára tekintettel állapít meg szigorúbb elbírálást. A különös és többszörös visszaesői minőség tehát nem jelenti ugyanannak a körülménynek a kétszeres értékelését, éppen ezért semmi nem zárja ki, hogy mindkét tényezőt egyszerre vegye figyelembe a büntetéskiszabás során a bíróság.

Így elvileg az a megoldás is felvetődhetne, hogy a büntetési tételek megemelésére is kétszer kerülne sor; egyik esetben felével emelkedik a tételkeret, mivel különös visszaesőről van szó, míg a másik esetben a már megemelt büntetési tétel emelkedne a felével, a többszörös visszaesői minőségre tekintettel. A büntetéskiszabási gyakorlatban ehhez hasonló helyzettel találkozunk akkor, amikor a többszörös vagy különös visszaesővel szemben halmazati büntetés kiszabására kerül sor, hiszen ekkor is kétszer emelkedik a felével a büntetési tétel. ${ }^{72} \mathrm{~A}$ bírói gyakorlat azonban nem ezt a büntetéskiszabási metódust alakította ki, hanem a büntetés kiszabása során a különös visszaesést „csupán” súlyosító körülményként értékelik. ${ }^{73} \mathrm{~A}$ gyakorlat szerint ebben az esetben a többszörös visszaesővel szemben szab ki büntetést a bíróság, a különös visszaesői minőségre pedig a határozat indokolásában kell csupán utalni. ${ }^{74}$

\footnotetext{
${ }^{69}$ Nem automatikus tehát a fegyház fokozat, csak abban az esetben kell fegyházban foganatosítani a végrehajtást, ha a kiszabott szabadságvesztés a 2 évet eléri vagy meghaladja. Lásd Btk. 37 . § (2) bekezdés ba) pont.

70 Btk. 38. § (4) bekezdés a) pont.

${ }^{71}$ Btk. 86. $\S(1)$ bekezdés a) pont.

72 Btk. 81. § (4) bekezdés alapján. Természetesen ez igaz azokra az esetekre, amikor a halmazatban lévő súlyosabb büncselekményre vonatkozik a különös visszaesés (BH 2001.5.207). A gyakorlatban felsőbb bírósági szinten előfordul ennek a jogszabályhelynek megfelelően az ítélet korrigálása, annak köszönhetően, hogy az elsőfokú bíróságok esetenként nem értelmezik helyesen a Btk. vonatkozó rendelkezéseit. Lásd például Szegedi Ítélőtábla Bf. 482/2017/19., Fővárosi Ítélőtábla 3.Bf.273/2017/5.

73 BLAskó Béla: Magyar Büntetőjog, Általános Rész. Rejtjel, Budapest-Debrecen, 2013, 542.

${ }^{74} \mathrm{BH}$ 2001.3.101., BH 1991.51.
} 
A többszörös visszaesői minőség értelemszerűen nem vehető figyelembe súlyosító körülményként, amennyiben a büntetést a különös és többszörös visszaesőre vonatkozó rendelkezés alkalmazásával határozták meg, hiszen ez már a kétszeres értékelés tilalmába ütközne. ${ }^{75}$ Nincs azonban akadálya annak, hogy a többszörös visszaesői minőséget megalapozón túli elítéléseket szintén súlyosító körülményként értékelje a bíróság. ${ }^{76}$ Sajnos vannak olyan elkövetők, igazi karrierbünözők, akiknél nagy kihívást jelent már a hiánytalan bủnlajstrom elkészítése is, és bizony számos esetben értékelhető a többszöri elítélés súlyosító körülményként.

\subsection{Erőszakos többszörös visszaesők}

Az erőszakos többszörös visszaesői kategória mintegy tíz éve létezik a magyar büntetőjogban. ${ }^{77}$ Bevezetésének indoka, hogy a 2009-es évben több nagy sajtónyilvánosságot kapó és a közvélemény kedélyeit is borzoló, sajnálatos erőszakos büncselekmény történt Magyarországon. ${ }^{78}$ Ekkor a politikai ellenzék egy törvényjavaslatot terjesztett elö, ${ }^{79}$ azzal a céllal, hogy a közbiztonságot Magyarországon helyreállítsa. A javaslat szerint a többszörös erőszakos visszaesőkkel szemben, az egyesült államokbeli „három csapás” 80 törvény szabályozásához hasonlóan, a harmadik alkalommal elkövetett, szándékos, személy elleni erőszakos bủncselekményre vonatkozó büntetés kiszabásánál szigorúbb büntetési tételt kell alkalmazni, és végső soron életfogytig tartó szabadságvesztés kiszabása indokolt a legsúlyosabb cselekményeket elkövetőkre. ${ }^{81}$

A „három csapás” vagy „három dobás” tehát egyáltalán nem magyar találmány, hiszen az Egyesült Államok több tagállamában és a szomszédos Szlovákiában is ismert jogintézményről volt szó. ${ }^{82} \mathrm{Az}$ előbb említett törvényjavaslat megszavazására ugyan nem került sor, de a Btk. novelláris módosításának a jegyében, 2009-ben bevezették az erőszakos többszörös visszaeső fogalmát a magyar büntetőjogba, ${ }^{83}$

${ }^{75} \mathrm{BH}$ 2003.1.7.

${ }^{76}$ Szegedi Ítélőtábla Bf. 482/2017/19., Zalaegerszegi Törvényszék 3. B.28/2017/28., Nyíregyházi Törvényszék 8.B.772/2017/97., Marcali Járásbíróság 7.B.38/2017/58/I., Fővárosi Ítélőtábla 16.Bf.250/2018/14.

${ }^{77}$ Ezt az új kategóriát a 2009. évi LXXX. törvény a Büntető Törvénykönyvről szóló 1978. évi IV. törvény módosításáról vezette be.

${ }^{78}$ Például az olaszliszkai lincselés, vagy a Marian Cozma gyilkosság. Az ilyen és ezekhez hasonló, kiemelten agresszív bűncselekmények a közvéleményt még inkább a szigorúbb büntetéskiszabás követelésének irányába mozdították el. Lásd SzABó Enikő: Bűnismétlők vs. büntetéskiszabás - a visszaesők megítélése, bűne és bűnhődése a magyar igazságszolgáltatás évszázadaiban. In: Jungi Eszter (szerk.): Büntetőjogi Tanulmányok XVII. kötet. MTA Veszprémi Területi Bizottsága, Veszprém, 2016, 114-115.

79 T/8875. számú törvényjavaslat.

80 Three Strikes Law.

${ }^{81} \mathrm{Az}$ amerikai három csapás törvényekröl lásd részletesen BEKE-MARTos Judit: Three Strikes Law, A három csapás törvénye Amerikában. Rendészeti Szemle, 2009/9, 97-110.

${ }^{82}$ A szlovák megoldást lásd részletesen FÁBRY Anton: A „Három csapás” büntetési elv bevezetése és ennek tapasztalatai Szlovákiában. Ügyészek Lapja, 2010/6, 127-133.

83 2009. évi LXXX. törvény a Büntető Törvénykönyvröl szóló 1978. évi IV. törvény módosításáról. A három csapás bevezetése igen élénk szakirodalmi reflexiókat váltott ki. Lásd ezekről részletesebben: KóNYA István: A három csapás bírói szemmel. Magyar Jog, 2011/3, 129-135.; NAGY Ferenc: Gondolatok az életfogytig tartó 
és szigorúbb jogkövetkezmények fogalmazódtak meg ezzel a bünismétlői kategóriával szemben. ${ }^{84} \mathrm{~A}$ valódi „három csapás” hazánkban végül csak 2010-ben került bevezetésre, a 2010. évi LVI. törvénnyel. A törvény indokolása értelmében a „2010. évi országgyülési választásokon megnyilvánuló választói akarat arra kötelezi az Országgyülést, hogy a (...) választók által támogatott büntetőpolitikai intézkedések a leghamarabb törvényeröre emelkedjenek". ${ }^{55}$ Ezzel a jogalkotó kimondottan olyan elkövetők szigorúbb szankcionálását tűzte ki célul, akik bünismétlőként sorozatban valósítanak meg személy elleni erőszakos büncselekményeket.

A jelenleg hatályos Btk. szigorú büntetőpolitikát hangoztató koncepciójába is jól illeszkedett az erőszakos többszörös visszaesőkkel szembeni szigorított fellépés, így magát a kategóriát és szigorú büntetőjogi szabályokat az új Btk. is megtartotta. Jelenleg erőszakos többszörös visszaeső az a többszörös visszaeső, aki mindhárom alkalommal személy elleni erőszakos bủncselekményt követett el. ${ }^{86} \mathrm{Az}$ erőszakos többszörös visszaesés tehát a többszörös visszaesés egy speciális esete, és magában foglalja a többszörös visszaesőkénti elítélés minden elemét, azzal a többlettel, hogy már a visszaesést megalapozó korábbi elítélés is személy elleni erőszakos búncselekmények miatt történt. Megállapításához az is szükséges, hogy a harmadik, személy elleni erőszakos büncselekményt az új törvény hatálybalépése után kövesse el az elkövető. ${ }^{87}$ A személy elleni erőszakos büncselekmények meghatározása nem bírói mérlegelés kérdése, hiszen a Btk. ezeknek a büncselekményeknek taxatív felsorolását adja. ${ }^{88}$

Elmondható, hogy a mai magyar büntetőjog legszigorúbban az erőszakos többszörös visszaesőkkel szemben lép fel. Az erőszakos többszörös visszaesővel szemben az erőszakos többszörös visszaesőkénti minősítést megalapozó bủncselekmény büntetési tételének felső határa szabadságvesztés esetén a kétszeresére emelkedik. Ha a büntetési tétel így felemelt felső határa a húsz évet meghaladná, vagy a törvény szerint a büncselekmény életfogytig tartó szabadságvesztéssel is büntethető, az elkövetővel szemben életfogytig tartó szabadságvesztést kell kiszabni. ${ }^{89}$ A Btk. Általános Része ezen kívül előírja, hogy az erőszakos többszörös visszaesővel szemben kizárt a feltételes szabadságra bocsátás lehetősége. ${ }^{90}$

$E$ két jogszabályhely együttes értelmezéséből az a következtetés vonható le, hogy egy abszolút büntetéskiszabási szabály született, és a bíróknak bizonyos esetekben,

szabadságvesztésről. Magyar Jog, 2013/5, 265-271.; NAGY Ferenc: A szabadságelvonással járó szankciókról az új Btk.-ban. Börtönügyi Szemle, 2014/4, 9. A halmazati három csapás alkotmányellenességét a 23/2014. (VII. 15.) AB határozat állapította meg. Lásd AMBRUs István: Az Alkotmánybírság határozata a halmazati három csapásról: a 23/2014. (VII. 15.) AB határozat. Jogesetek magyarázata (JeMa), 2015/4, 5-16.

${ }^{84} \mathrm{Az}$ általános büntetéskiszabási szabály, hogy a bűncselekmény büntetési tételének felső határa kétszeresére emelkedett. Ezen kívül még számos negatív jogkövetkezménye volt az erőszakos többszörös visszaesés megállapításának. Lásd részletesen SzABó: i. m. 116-117.

85 2010. évi LVI. törvény a Büntető Törvénykönyvröl szóló 1978. évi IV. törvény módosításáról, lásd részletesebben HoRvÁTH Eszter: A három csapás az alkotmányos büntetőjog tükrében. Jogelméleti Szemle, 2013/1, 46.

${ }^{86}$ Btk. 459. § (1) bekezdés 31. c) pont.

87 A Kúria 83. számú BK véleményében ( $\mathrm{BH} 2010 / 5)$.

${ }^{88}$ Btk. 459. $\S(1)$ bekezdés 26. pont.

${ }^{89}$ Btk. $90 . \S(2)$ bekezdés.

${ }^{90}$ Btk. 44. § (2) bekezdés a) pont. 
mérlegelést nem tűrően ki kell szabniuk a tényleges életfogytig tartó szabadságvesztés büntetést. A két jogszabályhely együttes értelmezése azonban a gyakorlatban vitákat generált, ezért a Kúria a 3/2020-as jogegységi határozattal igyekezett feloldani a jogértelmezési anomáliákat. A kérdés az volt, hogy vajon az erőszakos többszörös visszaeső csupán ezen alanyi körülmény miatt automatikusan ki van-e zárva életfogytig tartó szabadságvesztésre ítélés esetén a feltételes szabadságra bocsátás kedvezményéböl, vagy csak akkor, ha olyan büncselekményt követett el, ami eleve életfogytig tartó szabadságvesztéssel büntetendő, és a Btk. 44. § (1) bekezdésében szerepel. A Kúria arra az álláspontra helyezkedett, hogy nem automatikus az erőszakos többszörös visszaeső életfogytig tartó szabadságvesztésre ítélése esetén a feltételes szabadságra bocsátás lehetőségének a kizárása. Érvelése szerint „a Btk. 90. § (2) bekezdése szerinti automatizmushoz nem járulhat eleve egy újabb automatizmus, ha már az életfogytig tartó szabadságvesztés kiszabásához is egyfajta automatizmus útján jutunk el". Véleménye szerint tényleges életfogytig tartó szabadságvesztés ezzel az elkövetői kategóriával szemben csak akkor szabható ki, ha az erőszakos többszörös visszaeső által elkövetett cselekmény eleve életfogytig tartó szabadságvesztéssel is büntethető, tehát nem csak a büntetési tétel felső határának emelése folytán kerül sor az életfogytig tartó szabadságvesztés kiszabására.

Értékelendő, hogy a Kúria törekszik lazítani a Btk. szigorán ezzel az értelmezéssel, és igyekszik a mérlegelési jogától megfosztott bírót újra - legalábbis bizonyos esetekben - döntési pozícióba juttatni. A kúriai jogértelmezés azonban engem nem győzött meg - még ha tartalmával nagyon is egyetértek. Véleményem szerint ugyanis contra legem értelmezésnek minősül. Amennyiben a jogalkotó szándéka az lett volna, hogy csupán a 44. § (1) bekezdésében meghatározott büncselekmények elkövetése esetén zárja ki a bíróság a feltételes szabadságra bocsátás lehetőségét, úgy azt a jogszabályban jelölte volna, mint ahogy meg is tette a búnszervezetben történő elkövetés esetén. ${ }^{91} \mathrm{Az}$ abszolút büntetéskiszabási szabály problémájának megoldása kizárólag jogalkotói úton képzelhető el, és semmiképpen nem a törvény szövegével ellentétes értelmezéssel.

Anélkül, hogy megkérdőjelezném a tényleges életfogytig tartó szabadságvesztés létjogosultságát hatályos büntető szankciórendszerünkben, fel kell tennem a kérdést, hogy vajon megengedhető-e a büntetőjogban egy olyan szabály lefektetése a jogalkotó részéröl, amely az ügy egyedi körülményeinek a figyelembevétele nélkül a lehető legsúlyosabb szankció kiszabására kötelezi a bírót.

A magyar büntető szankciórendszer relatíve határozott, ami azt jelenti, hogy a szankció meghatározását illetően egy feladat- és munkamegosztás van a jogalkotó és a bíró között. ${ }^{92} \mathrm{~A}$ jogalkotó a Btk.-ban meghatároz egy büntetési tételkeretet, amelyen belül a bíró az egyéniesítés elvét szem előtt tartva, az ügy egyedi körülményeit is értékelve szabja ki a konkrét ügyben, a konkrét elkövetővel szemben a szankciót.

${ }^{91}$ Btk. 44. $\S(2)$ bekezdés szerint ki kell zárni a feltételes szabadságra bocsátás lehetőségét, amennyiben az elkövető a) erőszakos többszörös visszaeső, vagy b) az (1) bekezdésben meghatározott bűncselekményt bünszervezetben követte el.

92 PÁPAI-TARR Ágnes: Gondolatok a büntetéskiszabás néhány elméleti és gyakorlati kérdéséről. Pro Futuro, 2017/1, 21-25. (DOI: 10.26521/profuturo/2017/1/4745). 
A mérlegelést nem tűrően alkalmazandó életfogytig tartó szabadságvesztés ezzel szemben egy abszolút módon meghatározott büntetést jelent, ami lényegileg súlyosan sérti a bírói függetlenséget, és ellentétes a relatíve határozott szankciórendszerünk követelményével is. Az ügy egyedi jellegzetességeinek figyelmen kívül hagyása a konkrét ügyben igen súlyos következményekkel, és szükségképpen igazságtalanságokkal járhat. Hiszen alappal feltételezhető, hogy ki kell szabni a tényleges életfogytig tartó szabadságvesztést olyan ügyekben is, amikor a bíró meggyőződése szerint a konkrét elkövető esetén egyáltalán nem lenne rá szükség. A bíró mérlegelési joga gyakorlatilag a „mínusz tartományba” került át a három csapás következtében, szerepe pusztán a ténymegállapításra korlátozódik. ${ }^{93}$

A tudomány és a szakma neves képviselői ugyan kritikus véleményeket fogalmaztak meg a három csapás törvény vonatkozásában, mégis úgy tünik, hogy ebben a tekintetben a jogalkotó és a jogalkalmazó közötti munkamegosztás még mindig nem érvényesül, hiszen jogszabály-módosításra ez idáig nem került sor. Még neuralgikusabbnak tünik ennek a kérdésnek a megítélése, ha figyelembe vesszük azt a tényt, hogy a tényleges életfogytig tartó szabadságvesztés jelenlegi magyar szabályozása még mindig nem felel meg az európai emberi jogi mércének sem. ${ }^{94}$ Ebben a kérdésben nem a Kúria feladata lenne, hogy a jogszabály szigorán - egy a Btk. szövegével ellentétes értelmezés révén - igyekezzen enyhíteni, hanem kifejezetten jogalkotói feladat lenne a bíró mérlegelési jogának visszaállítása.

Érdekes büntetéskiszabási helyzetet teremt, amikor az erőszakos többszörös visszaesővel szemben halmazati büntetést kell kiszabni. Ebben az esetben ugyanis mind az erőszakos többszörös visszaesői minőségre tekintettel, mind a halmazati büntetéskiszabásra figyelemmel megemelkedik a büntetési tétel, egyszer a kétszeresére, aztán pedig a felével. Kérdés, hogy amennyiben így haladja meg a 20 évet a kiszabandó szabadságvesztés, akkor is életfogytig tartó szabadságvesztést kell-e kiszabni. Erre a kérdésre mind a bírói gyakorlatban, mind a Btk.-t módosító jogszabály indokolásában találunk választ. A Debreceni Ítélőtábla meggyőző okfejtéssel vezette le konkrét ügyben, hogy az erőszakos többszörös visszaesővel szemben az életfogytig tartó szabadságvesztést bünhalmazat esetén csak akkor lehet - de akkor kötelező kiszabni, ha a bủncselekmény büntetési tételének felső határa a húsz évet nem a halmazati büntetésre vonatkozó szabályok, hanem kizárólag az erőszakos többszörös visszaesésre tekintettel, a Btk. 90 . § (2) bekezdése alapján haladná meg. ${ }^{95}$

Az erőszakos többszörös visszaesővel szemben a Btk. a szabadságvesztést helyettesítő, alternatív szankciók kiszabását kizárja, illetve a Btk. 90. § (3) bekezdés a) pontja szerint az erőszakos többszörös visszaesővel szemben a büntetés a 82 . $§(1)$ bekezdése - enyhítő szakasz - alapján nem enyhíthető. Ennek megfelelően az

${ }^{93}$ KADLÓт Erzsébet: A jogos védelem és a tényleges életfogytig tartó szabadságvesztés a Btk.-ban. In: Hack Péter (szerk.): Hagyomány és megújulás a büntetőjogban. ELTE Bibó István Szakkollégium, Budapest, $2013,86$.

${ }^{94}$ A kötelező kegyelmi eljárás bevezetése sem oldotta meg a problémát, hiszen az EJEB előtt újabb elmarasztaló ítélet született Magyarország ellen. Lásd T. P. és A. T. kontra Magyarország ügy, 2016. október 4-ei ítélet (ügyszám: 37871/14 és 73986/14).

95 Debreceni Ítélőtábla Bf.II.62/2018/18., lásd továbbá a Btk. 81. § (4) bekezdését módosító 2015. évi LXXVI. törvény egyes büntetőjogi tárgyú törvények módosításáról 19-22. §-aihoz füzött miniszteri indokolást. 
erőszakos többszörös visszaeső egészen biztosan kizárólag végrehajtandó szabadságvesztés kiszabására számíthat, így törvénysértő a vele szemben kiszabott elzárás vagy közérdekü munka büntetés is. ${ }^{96}$

\section{Zárógondolatok}

Magyarországon a visszaeső bűnelkövetőkkel szemben a szigorú elbírálás, a kemény kéz büntetőpolitikája érvényesül. Ugyanakkor kriminológiai tanulmányok figyelmeztetnek arra, hogy a visszaesőkkel szembeni büntetőjogi eszközrendszer megválasztásakor nem elégséges a „keményen a bünözéssel szemben” elv alapján büntetni. ${ }^{97} \mathrm{~A}$ szabadságvesztés büntetés szükséges, de önmagában ezzel a szankcióval a bünözői életpálya nem igazán befolyásolható, és a visszaesők aránya sem feltétlenül csökkenthető. Sajnálatos módon ki kell mondanunk, hogy ennek a rendkívül összetett társadalmi problémának a megoldása jóval meghaladja a büntetőjog kereteit és lehetőségeit.

Az elkövető elöéletének alapos feltárása azonban vitathatatlanul fontos adat a büntetéskiszabást végző bíró számára. Addig, amíg a büntetlen előélet többnyire a vádlott javára értékelhető, addig a visszaeső bűnelkövetőkkel szemben alkotmányosan is elfogadott, hogy szigorúbban kell fellépni. ${ }^{98} \mathrm{~A}$ szigorított szabályok azonban rendkívül különbözőek, így alapvetően fontos és elvárt feladat a bíró részéröl a visszaesői minősítés helyes megállapítása, hiszen csak a helyes minősítés birtokában képzelhető el törvényesen kiszabott szankció. Az elkövető szempontjából pedig egyáltalán nem mindegy, hogy a bünismétlés milyen fokán áll, és melyik visszaesői minőség alapján kerül sor vele szemben a büntetés kiszabására.

A büntetéskiszabás bonyolult folyamata tehát soha nem lehet automatizmus a bíró részéröl, egyértelmüen elvárt követelmény az individualizáció, valamint a kétszeres értékelés tilalmának következetes figyelembevétele. Éppen ezért nem szerencsés a bíró kezének megkötése abszolút büntetéskiszabási szabály felállításával, amely bizonyos esetekben a bírót az ügy egyedi körülményeinek figyelembevétele nélkül tényleges életfogytig tartó szabadságvesztés büntetés kiszabására kötelezi.

Az elkövetők előéletével kapcsolatos joggyakorlat alaposabb feltárása is bizonyítéka annak, hogy a büntetéskiszabási szempontokat időröl időre érdemes felülvizsgálni. Gyakran még az 56. számú BKv.-ban egyértelműen megfogalmazott iránymutatásokat sem veszik figyelembe, vagy éppenséggel tévesen értelmezik a bíróságok. A büntetéskiszabás egységesítése érdekében sok esetben indokolt lenne egyes enyhítő vagy éppen súlyosító körülmények újragondolása, átértékelése, együttes előfordulásuk esetén az eddigi - talán már idejétmúlt - gyakorlat megváltoztatása.

\footnotetext{
${ }^{96}$ Kúria Bfv.III.604/2018/7.

97 KEREZSı Klára: A karrierbűnözés, karrierbünözők, bűnözői karrier. In: Gönczöl Katalin et al. (szerk.): Kriminológia-Szakkriminológia. Complex, Budapest, 2006, 576.

98 1214/B/1990 AB határozat. ABH 1995, 571.
} 